\title{
Warthin-like papillary thyroid carcinoma: A rare tumor of the thyroid
}

\author{
Warthin benzeri papiller tiroid karsinomu: Nadir bir tiroid tümörü
}

\author{
Nuray Can', Fulya Öz Puyan², Feriha Özz , Filiz Özyılmaz², Şemsi Altaner², \\ Zeynep Pehlivanoğlu ${ }^{2}$, A. Kemal Kutlu² \\ ${ }^{1}$ Şanlıurfa Education and Research Hospital, Department of Pathology, Şanluurfa, Turkey \\ ${ }^{2}$ Medical Faculty of Trakya University, Department of Pathology, Edirne, Turkey \\ ${ }^{3}$ German Hospital, Department of Pathology, Istanbul, Turkey
}

Geliş Tarihi / Received: 29.03.2011, Kabul Tarihi / Accepted: 12.08.2011

\begin{abstract}
Warthin-like papillary thyroid carcinoma is a rare variant of papillary thyroid carcinoma with favorable prognosis. The tumor is named "Warthin-like papillary thyroid carcinoma" because of bearing a striking morphological resemblance to Warthin's tumor occurring in the salivary glands. Thyroid ultrasonography of 65 years old female patient with a history of bilateral subtotal thyroidectomy 30 years ago in another center with unknown histopathological diagnosis revealed a $20 \mathrm{~mm}$ isoechoic solid nodule in the left lobe and this nodule was hypoactive in thyroid scintigraphy. Grossly, a grey-tan colored, solid nodule with $1 \mathrm{~cm}$ diameter was seen in the left lobe. Histologically, the tumor was composed of papillary structures surrounded by marked lymphocytic stroma and oncocytic cells with papillary carcinoma's nuclear features were lining the papillae. Hashimoto's thyroiditis was present throughout the thyroid. Immunohistochemically, tumor cells exhibited cytokeratin 19, Thyroid transcription factor-1 (TTF-1), Galectin-3, HBME-1(Mesothelioma antibody) and thyroglobulin positivity, proliferative index with Ki-67 was low. Warthin-like papillary thyroid carcinoma is a rare variant of papillary thyroid carcinoma and other oncocytic cell lesions especially Hurthle cell carcinoma should be kept in mind in the differential diagnosis of this neoplasm.
\end{abstract}

Key words: Thyroid, carcinoma, Warthin-like tumor

\section{INTRODUCTION}

Papillary thyroid carcinoma is the most common type of thyroid carcinoma and generally has a more favorable prognosis than other carcinoma types. ${ }^{1}$ Several variants of papillary thyroid carcinoma have been defined. ${ }^{2}$ In 1995, Apel et al. reported a new

\section{ÖZET}

Warthin benzeri papiller tiroid karsinomu, iyi prognozlu nadir görülen papiller karsinom varyantıdır. Tümör, ismini tükrük bezinin Warthin tümörüne morfolojik olarak benzerliğinden almaktadır. Başka bir merkezde 30 yıl önce bilateral subtotal tiroidektomi uygulanan ancak histopatolojik tanısı bilinmeyen 65 yaşındaki kadın hastanın yapılan tiroid ultrasonografisinde, sol lobta $20 \mathrm{~mm}$ çapında izoekoik solid nodül ve tiroid sintigrafisinde aynı lokalizasyonda hipoaktif nodül görüldü. Makroskopik olarak, sol lobta $1 \mathrm{~cm}$ çapında kirli beyaz renkli, solid kıvamda nodüler lezyon tespit edildi. Mikroskopik olarak, sol lobta lenfositten zengin stroma ile çevrili papiller yapıları döşeyen, papiller karsinomun nükleer özelliklerine sahip, onkositik sitoplazmalı hücrelerden meydana gelen tümör izlendi. Tümör dışı tiroid dokusunda Hashimoto tiroiditi mevcuttu. İmmünohistokimyasal çalışmalarda tümörde sitokeratin 19, TTF-1 (Thyroid transcription factor-1), Galektin3, HBME-1 (Mesothelioma antibody) ve tiroglobulin ile pozitiflik mevcuttu, Ki-67 proliferatif indeksi düşüktü. Warthin benzeri papiller tiroid karsinomu nadir görülen papiller karsinom varyantı olup, ayırıcı tanıda diğer onkositik hücreli lezyonlar ve de özellikle Hürthle hücreli karsinom akılda tutulmalıdır.

Anahtar kelimeler: Tiroid, karsinoma, Warthin benzeri tumor

variant of papillary thyroid carcinoma composed of papillary structures lined by oncocytic cells with nuclear features of papillary thyroid carcinoma in lymphocytic stroma with series of 13 cases and named this type of tumor 'Warthin-like papillary thyroid carcinoma' relying on the histological resemblance 
of 'Warthin's tumor' of salivary glands. ${ }^{3}$ Warthinlike papillary thyroid carcinoma, is a relatively uncommon variant of papillary thyroid carcinoma. It usually appears as a cystic or solid-cystic thyroid nodule. ${ }^{4}$ Histologically, large, polygonal cells with abundant eosinophilic, finely granular cytoplasm lines on the papillae surrounded by dense chronic inflammatory infiltrate, consisting of predominantly lymphocytes and plasma cells. Differential diagnosis of this neoplasm from a florid chronic thyroiditis, Hurthle cell nodules in chronic lymphocytic thyroiditis ${ }^{5}$, Hurthle cell tumors, tall cell and oncocytic variants of papillary thyroid carcinoma and oncocytic variant of medullary carcinoma can be very difficult in fine needle aspiration cytology and also in the histological examination. ${ }^{4}$

\section{CASE}

A 65 years old female patient had underwent bilaterally subtotal thyroidectomy in another hospital 30 years ago. No histopathological diagnosis about this operation was available. She admitted to surgery clinic with complaints such as hot flushes, irritability, excessive sweating, palpitation and heat intolerance, which were progressively increasing in recent five years. Thyroid functions tests showed high levels of T3, T4 and TSH level was reduced. In the left lobe, middle part, an isoechoic solid nodule sized 20x14x13 mm was recognized by thyroid ultrasonography. Thyroid scintigraphy signified the hypoactive nodule at the same localization with ultrasonography.

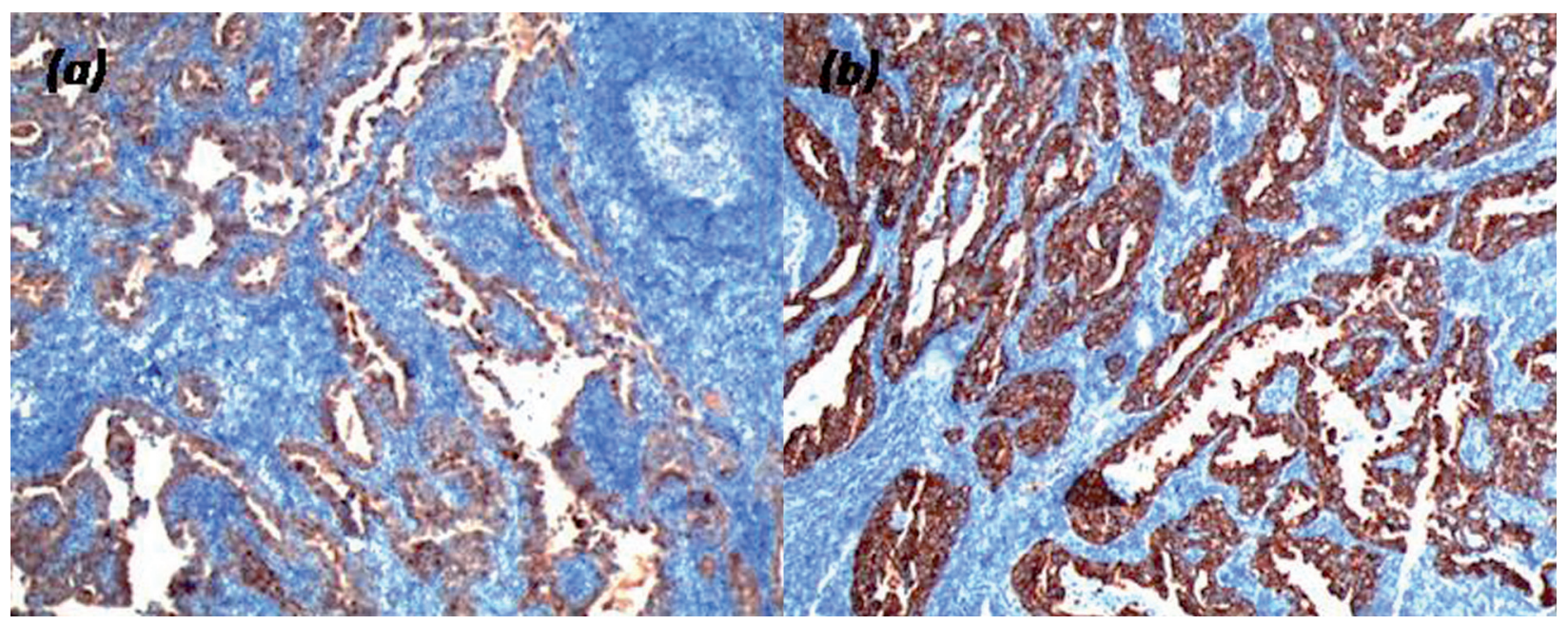

Figure 1. (a) Oncocytic cells lining the papillary structures embedding in a rich lymphoid stroma with germinally centers (H\&E x50), (b) intranuclear inclusion and grooves (H\&E x400).

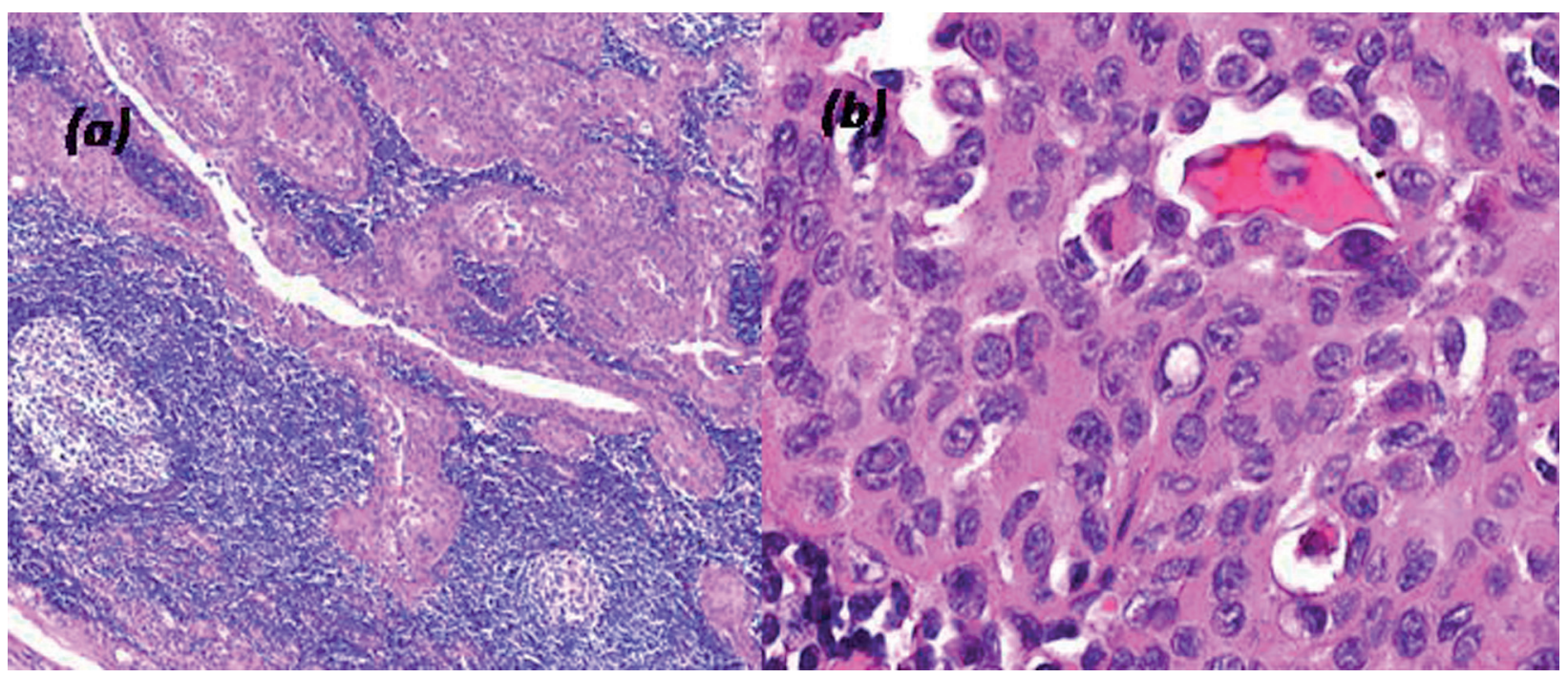

Figure 2. (a) Cytokeratin 19 positivity (Cytokeratin 19 x50), (b) Galectin 3 positivity (Galectin 3 x50). 
Complementary bilaterally thyroidectomy was performed. Grossly, bilaterally thyroid lobe seemed pale and lack of colloid. A partially circumscribed, grey-tan colored solid nodule with $1 \mathrm{~cm}$ diameter was noticed in the left lobe. In histological examination, Hashimoto's thyroiditis was seen throughout the thyroid. Slides representing the nodule that seen in the left lobe showed an unencapsulating tumor consisting of the papillary architecture embedding in a rich lymphoid stroma that also containing germinally centers (Figure 1a.). Papillary structures were lined by oncocytic cells implying papillary carcinoma nuclei such as chromatin clearing, pseudonuclear inclusions, and grooves (Figure 1b). Immunohistochemically, tumor cells exhibited cytokeratin 19, Galectin-3 (Figure 2a and 2b), TTF-1, HBME-1, thyroglobulin positivity and proliferative index with Ki-67 was 2-3\%. Diagnosis of 'Warthinlike papillary thyroid carcinoma' was rendered based on these pathological features.

\section{DISCUSSION}

The oncocytic variant of papillary thyroid carcinoma with lymphoid stroma as a distinctive entity has been firstly reported by Apel et al., after that it has been named as 'Warthin-like papillary thyroid carcinoma' in 1995.,3 Most of the patients are female (90\%), and age of onset ranges between $23-85$ years. Tumor size varies among 0.3 to $5.0 \mathrm{~cm}$ in diameter (mean $2.0 \mathrm{~cm}$ ). The crucial histological features are stromal lymphocytic infiltration with the oncocytic character of epithelial cells, which cause a strong resemblance to Warthin's tumor of the salivary gland. The tumor cell nuclei have classical papillary carcinoma properties. In more than $90 \%$ of the cases, lymphocytic thyroiditis is present at the same time. ${ }^{2}$ In the present case, the entire thyroid was occupied by Hashimoto's thyroiditis and there was an unencapsulated tumoral nodule embedded in lymphocytic stroma with germinally centers. The tumor was consisting of papillary structures lined by oncocytic cells revealing nuclear features of conventional papillary carcinoma.

The prognosis is favorable as conventional papillary carcinoma in most reported patients but experiences about follow-ups are limited. ${ }^{2}$ Some authors reported that $30 \%$ of the cases have revealed lymph node metastasis and extrathyroidal extension. According to our knowledge, only two cases reported to date showed worse prognosis; one with anaplastic features and one with dedifferentiated component. ${ }^{4}$ It was reported that the lymphocytic stroma is a result of an autoimmune response encompassed by papillary carcinoma ${ }^{6}$ so that its recurrence rate is significantly lower in those showing lymphocytic infiltration. These data suggest a favorable prognosis for Warthin-like tumor. ${ }^{2}$ In the reported case, there was no lymph node metastasis or extrathyroidal extension. Although, we sampled the entire tumor, we could not determine anaplastic or dedifferentiated component.

Differential diagnosis of Warthin-like papillary thyroid carcinoma includes some other variants of papillary carcinoma (such as tall cell variant, Hurthle cell variant, diffuse sclerosing variant), Hurthle cell carcinoma, Hashimoto's thyroiditis and extraparotideal Warthin's tumor.

Hurthle cell carcinoma, especially papillary variant differentiates from Warthin-like papillary carcinoma by lacking of nuclear features of conventional papillary carcinoma. Tall cell variant papillary carcinoma is characterized by tall columnar cells with basally located elongated nuclei although eosinophilic cytoplasm and dominant lymphocytic infiltration can be seen. The most striking feature that differentiates this tumor from Hurthle cell variant is the lack of lymphocytic infiltration of the latter. Diffuse sclerosing variant has heavy lymphocytic infiltration but also it is characterized by the diffuse involvement of one or both thyroid lobes, dense sclerosis, abundant psammoma bodies, extensive solid foci, and squamous metaplasia. Papillary mass of oncocytic cells with nuclear features of papillary carcinoma are not observed in Hashimoto's thyroiditis, at the same time the nuclei in Hashimoto's thyroiditis are more pleomorphic than papillary carcinoma. ${ }^{1,2}$ Although about $8 \%$ of Warthin's tumors can be seen in extraparotideal locations such as in the lymph nodes of the cervical region, submandibular gland, minor salivary glands of the oral cavity, pharynx, and larynx, real extraparotideal Warthin's tumor are not expected to be at any other site than cervical nodes and does not exhibit the nuclear features of papillary carcinoma. ${ }^{7}$ In the differential diagnosis of the reported case included a non-neoplastic nodule in Hashimoto's thyroiditis and extraparotideal Warthin's tumor but observation of the nuclear features of papillary carcinoma and immunohistochemical findings ensured 
the diagnosis of Warthin- like papillary thyroid carcinoma.

In conclusion, although Warthin- like papillary thyroid carcinoma is a rare variant of papillary thyroid carcinoma and there is limited knowledge about its prognosis, it composes an important place in the spectrum of differential diagnosis of oncocytic lesions that contains Hashimoto's thyroiditis at one end and the Hurthle cell carcinoma on the other end.

\section{REFERENCES}

1. Sarkady E, S'api Z, T' oth V, Kiss S. "Warthin-like tumor of the thyroid-a case report". Pathol Oncol Res 1999; 5(4): 315-7.

2. Chang Sig Choi SHC, Kim YS. Warthin-like tumor variant of papillary thyroid carcinoma - A case report. Korean J Pathol 2004; 38(3): 200-3.
3. Apel RL, Asa SL, LiVolsi VA. "Papillary Hurthle cell carcinoma with lymphocytic stroma: "Warthin-like tumor" of the thyroid”. Am J Surg Pathol 1995; 19(7): 810-4.

4. Amico P, Lanzafame S, Li Destri G, et al. Warthin tumor-like papillary thyroid carcinoma with a minor dedifferentiated component: Report of a case with clinicopathologic considerations. Case Reports in Medicine 2010 PMID 495281, 5 pages doi:10.1155/2010/495281

5. Montone KT, Baloch ZW, LiVolsi VA. "The thyroid Hurthle (oncocytic) cell and its associated pathologic conditions: a surgical pathology and cytopathology review". Arch Pathol Lab Med 2008; 132(8):1241-50.

6. LiVolsi VA. Papillary neoplasms of the thyroid. Pathologic and prognostic features. Am J Clin Pathol 1992; 97(3): 42634.

7. Astor FC, Hanft KL, Rooney P, Benson CA, Flores CT, Lavertu P. Extraparotid Warthin's tumor: clinical manifestations, challenges, and controversies. Otolaryngol Head Neck Surg 1996; 114(6): 732-5. 